\title{
Buy-Out of the Oppressed Minority's Shares in Joint Stock Companies: A Comparative Analysis of Turkish, Swiss and English Law*
}

\section{Cem Veziroğlu*}

\section{Introduction}

Shareholders representing at least ten per cent of the share capital in joint stock companies ${ }^{1}$, and five per cent in publicly traded companies ${ }^{2}$, are granted the right to request corporate dissolution for just causes under Article 531 of the Turkish Commercial Code No. 6102 (“TCC"). ${ }^{3}$ The provision, however, equips the court with a wide remedial discretion, such as ordering the purchase of the claimant's shares at real value (buy-out remedy) or adopting another appropriate solution, in lieu of corporate dissolution. Considering, inter alia, external stakeholders' interests ${ }^{4}$ and traditional avoidance of judges in civil law jurisdictions from actively intervening into corporate affairs ${ }^{5}$, it is anticipated that the buy-out will be the most frequently adopted remedy by Turkish judges. Indeed this has already been signalled by the Turkish Court of Appeal's ("TCA") decisions to date. ${ }^{6}$

Therefore this study conducts an economic analysis of buy-out remedy for oppressed minorities in joint stock companies under TCC Article 531 and compares Turkish law with Swiss and English jurisdictions. The article addresses certain critical questions that have arisen in practice, rather than reviewing the issue in all its aspects. Since Turkish company law is heavily influenced by Swiss law in general, and more particularly, TCC

* This is a pre-print of an article published in European Business Organization Law Review. The final authenticated version is available online at: https://doi.org/10.1007/s40804-018-0103-9. I am grateful to Mehmet Helvacı, Tolga Ayoğlu, H. Ali Dural, Jeremias Prassl, Kerem Cem Sanlı, Ayşe Şahin, Emek Toraman Çolgar, an anonymous referee and participants in Scholars' Colloquium of 2016 Summer Institute in Law \& Economics at Coase-Sandor Institute for Law and Economics, as well as the American Society of Comparative Law - Younger Comparativists Committee's 6th Annual Conference at Koç University on 28 April 2017 for their valuable comments. I am also grateful to Dr. Nüsret - Semahat Arsel International Business Law Implementation and Research Center (NASAMER) of Koç University Law School for their funding of my visit to Coase-Sandor Institute for Law and Economics.

* cveziroglu@ku.edu.tr. MJur (Oxon); Research/Teaching assistant, Koç University Law School, Istanbul, Turkey; PhD candidate, University of Istanbul, Istanbul, Turkey.

1 The term "joint stock company" is used for "anonim şirket" in Turkish law, "Aktiengesellschaft" in Swiss law and "public company limited by shares" in English law.

2 This study does not conduct a separate analysis for publicly traded joint stock companies, since buy-out remedy within an action for judicial dissolution is only expected to be applied in privately held companies. Investors in publicly traded companies are already protected by capital markets law and regulations, as well as a liquid market for shares.

3 Prior to the TCC's entry into force on 1 July 2012, dissolution of joint stock companies for just causes was neither codified nor applied in case law.

4 TCC Article 531 orders the court to consider third parties' interests, as well as those of the claimant and the company in question by requiring the solution to be "appropriate for the case and acceptable".

5 The (formerly) traditional non-interventionist attitudes of English judges were challenged by introduction of the unfair prejudice remedy in CA 1980. See Davies/Worthington 2016, para 20-3.

6 See fn. 45-47. 
Article 531 is received from the Swiss Code of Obligations ("SCO") Article 736/47, Swiss jurisdiction is inherently a point of reference for our research. Besides that, English law accommodates historical foundations of the buy-out remedy for aggrieved minorities which is currently enshrined in sections 994-999 of the Companies Act ("CA") 2006 under the title "Protection of Members Against Unfair Prejudice". Hence the common law principles that have developed around a dynamic case law ${ }^{8}$ may serve as a useful guide for both Swiss and Turkish lawyers. Moreover, since the purchase of the claimant's shares is the most commonly ordered remedy by English judges ${ }^{9}$, English common law has a significant importance in respect of this research. Nevertheless it is interesting to observe the Turkish doctrine's conventional approach towards only taking into account Swiss and/or German law while ignoring such a valuable source of common law.

The first part of the paper makes the case for regulating the corporate contract ${ }^{10}$ and explains the purpose of the buy-out remedy, whereas the second part deals with the shortcomings of the TCC Article 531. Swiss, Turkish and English jurisdictions are compared with a functional approach along the paper, in order to recommend specific solutions for each problem, rather than drawing a general description thereof.

\section{Regulation of the Corporate Contract and Purpose of the Remedy}

Due to its long-term and complex ${ }^{11}$ nature, 'complete' corporate contract seems practically impossible and financially undesirable. ${ }^{12}$ Compared to one-off agreements, market failures are inevitably more obvious in corporate contracts, inasmuch as unequal negotiation power and informational asymmetries prevent minorities from stipulating protective mechanisms at the investment stage, ie. formation of company or acquisition of shares. Furthermore the majority rule within decision making mechanisms may easily operate to minority's detriment thereafter. Indeed erga omnes effect of decisions of general assembly and board of directors allows controller to take opportunistic decisions. More importantly, minorities in privately held joint stock companies ${ }^{13}$ are mostly locked in as a result of share transfer restrictions or lack of a liquid market for shares. Therefore they are devoid of the market-based governance mechanisms ${ }^{14}$, as well as contractual protections.

7 Preamble of Article 531 of the draft TCC explicitly refers to SCO Article 736/4 as the source of the rule, see http://www2.tbmm.gov.tr/d22/1/1-1138.pdf. Accessed 29 May 2017

8 Although most of the unfair prejudice cases concern quasi-partnership companies, CA 2006 sections $994-999$ apply to all types of company. See Re a Company (No 00314 of 1989) [1991] BCLC 154; Mayson/French/Ryan 2016, p. 576.

9 See fn. 48.

10 The term "corporate contract" expresses here the contractual relationships amongst shareholders inter se and between the company and shareholders that are established by the articles of association and shareholders' agreements.

11 Intra-corporate relationships are more complex than other contracts due to re-drafting of the articles of association, existence of shareholders' agreements and understandings amongst shareholders. See Riley 1992, pp. 785-786.

12 Gordon 1989, p. 1592; Prentice 1988, p. 59; Kraakman et al. 2009, p. 24.

13 Joint stock companies are allowed to offer their shares to the public, but may have in fact chosen not to do so.

14 According to the theory of 'market for corporate control', share price decreases with the managers' poor performance; the threat of the company's becoming a target for takeover disciplines the management who wants to keep their office. See Manne 1965, p. 119. According to the 'efficient capital markets hypothesis' all relevant information is already impounded into share price, thus internalized ex ante in the bargain. See Gilson/Kraakman 1984, pp. 569-572. 
Hence regulation of corporate contract by enabling minority shareholders to force corporate dissolution in cases of serious oppression is justified by these market failures. ${ }^{15}$ In fact, many jurisdictions prescribe individual or minority exit rights and/or right to force corporate dissolution in order to escape opportunistic controllers. ${ }^{16}$ Correspondingly the buy-out remedy mainly aims to protect minorities against abuse of the majority rule ${ }^{17}$ by giving the claimant an opportunity to exit with a fair value of her investment, which is usually impossible. ${ }^{18}$

The ratio legis of the remedy may be better explained with an example. The controller, for instance, receives excessive payments as a board member while other shareholders are consistently deprived of dividend. In this way the controller can raise her wealth by indirectly appropriating corporate assets, whereas it generates losses for the company. Firstly, the company may lose credibility in the eyes of creditors and potential investors which, in turn, may increase its financing costs. Additionally, the value of shares may decrease in parallel with the reduction of corporate assets. Consequently, negative externalities may arise upon the minority where there is profit for the controller in pursuing this behaviour. Nonetheless, the order for purchase of the minority's shares is to function as a kind of put option conditional upon serious oppression. ${ }^{19}$ Such a threat sweeps potential profit for the controller by raising the 'costs' side of equation due to litigation and valuation processes, as well as the purchase price. These costs constitute the implicit price ${ }^{20}$ of the controller's oppressive conducts. As a result, the buy-out remedy is supposed to ex ante incentivize the controller towards respecting the minority's interests. ${ }^{21}$

However the current provision is not designed so as to provide the expected incentives. The below explained shortcomings may lead to opportunistic behaviours of both the minority and the controller, and the legal gaps within the provision (lücken intra legem) may generate serious ambiguities and challenges for judicial interpretation in practice.

\section{Shortcomings of TCC Article 531}

\section{A. Standard of 'Just Causes'}

While corporate dissolution is provided in the same provision with other remedies under Turkish (TCC Article 531) and Swiss (SCO Article 736/4) laws, they are stipulated in separate codes (CA 2006 sections 994999 and Insolvency Act 1986 section 122/1-g) under English law. This connection between distinct remedies in TCC and SCO leads to adopting a same standard of 'just cause' for each remedy, ie. dissolution, purchase of the shares and other solutions. It is widely accepted in the doctrine that the court may order a remedy only if the

15 Girod 1986, p. 38; Prentice 1988, p. 61.

16 See examples in Kraakman et al. 2009, p. 161.

17 Bürgi 1969, Article 736 para 39; Beeler/von de Crone 2010, p. 332; Tekinalp 1974, p. 324; Çamoğlu 2008 , p. 63.

18 Davies/Worthington 2016, para 20-19; Birds 2013, para 30.994.02.

19 Kraakman et al. 2009, p. 161.

20 Cooter/Ulen 2016, p. 3; Sanlı 2007, p. 14.

21 Tekinalp 1974, p. 322; Due to its costs, the right of dissolution is considered mainly a negotiation tool in cases of oppression, see Kraakman et al. 2009, p. 162. 
facts justifying dissolution of the company are proven at the case. Otherwise the court must necessarily dismiss the action regardless of the remedy sought. ${ }^{22}$

However requiring an equal level of just causes for different remedies may distort the intended incentives. In our view, the remedy to be adopted has to vary according to the gravity of just cause present at the case. In cases where the facts do not justify dissolution of the company in question, the court should not directly dismiss the case. To be more precise, the court should be able to adopt an alternative solution, such as the buyout of the minority's shares, even if the facts do not justify dissolution of the company in question. Otherwise, negative externalities upon minority shareholders cannot be removed in the event that the controller's abusive conducts do not reach to the level of 'just cause' in the sense of TCC Article 531.

It must be noted here that the judicial dissolution is considered as ultima ratio, because its effects are is much wider than other remedies. Dissolution of the company in question not only deprives the controller from private benefits of control, but also creates costs for other stakeholders, such as creditors, employees and the society. Therefore dissolution seems to be inefficient, in cases where there is a going concern to be protected even if there are 'just causes' in the sense of TCC Article $531 .^{23}$

Tracing back the legislative history of dissolution and buy-out remedies under Turkish, Swiss and English laws may help to clarify their relationship and its effect upon the problem of just cause standard. In 1936 Swiss legislator introduced the remedy of corporate dissolution for just causes into SCO Article 736/4, and no alternative remedies were provided then. ${ }^{24}$ Subsequently, "other solutions" were added into the provision as a result of the amendment that entered into force on 1 July $1992 .{ }^{25}$ Currently, corporate dissolution and alternative remedies, including share buy-out ${ }^{26}$, are provided in the same provision under Swiss law. Dissolution of joint stock companies for just cause was first introduced into Turkish law in 2012 with the enactment of TCC Article 531, which was received from SCO Article 736/4. As in Swiss law, Turkish law provides for corporate dissolution and alternative remedies in the same provision which does not require different levels of 'just causes' in order to apply distinct remedies.

22 For Turkish law see Oruç 2011, p. 227; Çamoğlu 2015, p. 10; Şahin 2013, p. 125; Nomer Ertan 2015, p. 428; cf. Tekinalp 2013, p 218. Tekinalp dissents from the majority opinion by arguing that 'just causes' do not always need to justify a dissolution. In line with the majority opinion in Swiss law, see Lüscher 1992, p. 179; Beeler/von de Crone 2010, p. 337. The threshold problem is more controversial in Swiss law, since "other solutions" were added into SCO Article 736/4 later in 1992, and thus, it is argued that the new availability of ordering less severe measures will increase the willingness of judges to accept the existence of just causes. See Honsell/Vogt/Watter, Article 736 para 23.

23 The TCA has expressly adopted this view. See TCA 11. Civil Division Date 2.6.2014, Case No. 2014/3669, Decision No. 2014/10238; Date 3.3.2016 Case No. 2015/9088 Decision No. 2016/2352: "According to company law, it is essential to maintain the company's continuity; pursuant to the provision [TCC 531] the judge is required to consider other solutions that would maintain the company carrying an economic value, rather than dissolution" (the author's translation).

24 Bürgi 1969, Article 736 para 38.

25 Dessemontet/Rapp/Stoffel 1993, p. 861.

26 While TCC Article 531 expressly indicates "purchase of the claimant's shares", SCO Article 736/4 contents with stating "other solutions". However, it is accepted in Swiss law that "other solutions" include the buy-out remedy, see fn. 43. 
Under English law, the statutory remedy of "just and equitable winding up" ${ }^{27}$ has existed since the Joint Stock Companies Winding Up Act 1848. However the only remedy available then was winding up. As a result of the Cohen Committee's ${ }^{28}$ recommendations, alternative remedies including the purchase of petitioner's shares were prescribed in section 9 of CA 1947 with the title of "Alternative Remedy to Winding Up In Cases of Oppression”. During the period between 1947 and 1986, just and equitable winding up and alternative remedies were found in the same codes, respectively CA 1947, CA 1948, CA 1980 and CA 1985. However, the link between the two norms were making it difficult for the claimant to succeed, since it was required to show not only that the company's affairs are being conducted in an oppressive manner, but also that it would have been just and equitable to wind up the company. ${ }^{29}$ In accordance with the Jenkins Committee's ${ }^{30}$ recommendations, this connection was repealed with the enactment of the CA 1980, thereby alternative remedies could be ordered without proving the facts that would justify winding up of the company. Moreover, winding up remedy was totally removed from the CA and incorporated into the Insolvency Act 1986 section 122/1-g.

The legislative history of the buy-out remedy under English law leads us to the conclusion that it was derived from just and equitable winding up. Moreover the close connection between these two remedies has been repealed, and buy-out has become a distinct legal instrument available for oppressed shareholders. In this way the minority protection regime under English company law has been strengthened. Hence we hope that Turkish and Swiss legislators consider the challenges arising from the link between the two remedies that had been experienced in English law between 1947 and 1980.

However, one cannot claim that the ideal model is to isolate these remedies (buy-out and dissolution) from each other. Indeed the Law Commission recommended to add winding up order into the remedies' list available under unfair prejudice mechanism found in CA 2006 sections 994-999. ${ }^{31}$ This recommendation was based on the concern that winding up order cannot be given in an action for unfair prejudice, since it is required to apply for just and equitable winding up to claim such remedy. ${ }^{32}$ Although a petition for unfair prejudice can be combined with an application for just and equitable winding up, differences between the two legal instruments in terms of their scope and requirements may complicate matters. ${ }^{33}$ Therefore, we are in the opinion that these remedies should be provided within a single provision, with differing standards of 'just causes' proportionate to the remedy sought. Thereby, the court would be able to adopt an appropriate solution as it thinks fit considering the facts of the case, and the claimant's request would not be rejected just because the facts do not justify dissolution of the company in question.

\footnotetext{
27 "Just and equitable winding up" corresponds to "corporate dissolution for just causes", in that a winding up order may be requested in cases of oppression. We use the former for English law and the latter for Turkish and Swiss laws in order to comply with the legislators' preference in their respective codes.

28 Report of the Committee on Company Law Amendment (1945) Cmd 6659, para 60.

29 Birds 2013, para 30.944.27.

30 Report of the Company Law Committee, Cmnd. 1749, June 1962, para 212.

31 The Law Commission Report “Shareholders' Remedies”, Law Com No 246, Cm. 3769, October 1997, para 4.24-4.49.

32 Davies/Worthington 2016, para 20-21; Worthington 2016, p. 717.

33 The Law Commission Report “Shareholders' Remedies", Law Com No 246, Cm. 3769, October 1997, para 4.24.
} 


\section{B. Court's Wide Remedial Discretion}

TCC Article 531 grants minority shareholders merely the right to request corporate dissolution. However the court may give an order for the purchase of the claimant's shares or adopt a different solution, rather than dissolving the company. It follows that the minority does not have a 'right' to leave the company and the court has a wide remedial discretion by delivering an extra petita judgment. ${ }^{34}$ The uncertainty of outcome eventually affects the threat value of the mechanism and complicates the intended incentives on both sides.

The court's wide remedial discretion, on the one hand, gives the minority an unfair bargaining advantage by putting pressure on the controller ${ }^{35}$ and subjecting the company in question to prolonged uncertainty. ${ }^{36}$ The minority may use the threat of judicial dissolution as a tactical litigation. Assume that the cost of dissolution for the controller is $\$ 100$ and the "real value" of the minority shares is $\$ 20$. The majority would be ready to pay any amount below $\$ 100$ for minority shares in order to evade from a corporate dissolution. The minority can, thus, unfairly profit by receiving any amount above the real value of her shares.

On the other hand, the minority may abstain from using this legal tool, since the court's order may differ from her actual request. For instance, the court may give a buy-out order, even if the claimant only expected a dividend distribution, or vice versa. A similar case would be an order of dissolution whereas the minority sought to be bought out. Such uncertainty may eventually decrease the incentives of the majority to respect minority rights. It may be argued that the minority is deemed to have accepted in the first place to leave the company $a$ fortiori by filing an action for dissolution under TCC Article 531. Although both dissolution and buy-out demands aim to end membership to the company ${ }^{37}$, their economic results diverge, in that the claimant receives liquidation value of her shares if the company dissolves, whereas she receives 'real value' if bought out. Therefore seeking a buy-out order may not necessarily include consent to a dissolution order. However it must be reminded here that according to TCC Article 531 the court is not bound with the claimant's will.

In our view, de lege ferenda the claimant should have a say in the outcome of the proceeding. Particularly the court should be bound with the claimant's explicit will towards staying in the company. In such a case, the court should refer to alternative remedies, rather than dissolution or buy-out. However this problem cannot be achieved through judicial interpretation, but a legislative reform is needed. Yet the problem can be partially solved by taking into account the claimant's will to stay as a shareholder. ${ }^{38}$

\footnotetext{
34 Yasaman 2009, pp. 92-93; Erdem 2012, p. 266; Tekinalp 2013, p. 220; Şahin 2013, pp. 428-429; Ayoğlu 2013, p. 237.

Worthington 2016, p. 719.

36 Company Law Review, Modern Company Law for a Competitive Economy: Developing the Framework, URN 00/656, March 2000, para 4.105.

37 Oruç 2011, pp. 222-223; Ayoğlu 2013, p. 240.

38 Şahin 2013, p. 430. Şahin recommends that courts should give priority to the alternative remedy specified in the claimant's petition. In the same direction, see Ayoğlu 2013, p. 243. Indeed the TCA took into account the claimant's will to be bought out in two cases where it reversed the judgement of first instance. See TCA 11. Civil Division Date 2.6.2014, Case No. 2014/3669, Decision No. 2014/10238; Date 3.3.2016 Case No. 2015/9088 Decision No. 2016/2352.
} 
While Swiss ${ }^{39}$ and English laws ${ }^{40}$ do not differ from Turkish law on the court's wide remedial discretion, according to English law the petitioner must specify the relief she seeks and the request must be appropriate to the conduct complained of. ${ }^{41}$ Moreover, English courts' almost always take the claimant's will to be bought out into account, and it is argued that the frequency of buy-out order seems to render this relief a 'right' accruing to the claimant once the unfair prejudice grounds are established. ${ }^{42}$

In fact TCC Article 531 approximates to English law by expressly articulating the buy-out order as CA 2006 section 996/2-e does, and diverges from Swiss law in this regard. Because SCO Article 736/4 only prescribes dissolution order and 'other solutions'. The difference between the wording of Turkish and Swiss legislations has already been reflected in the respective countries' case law. Although it is accepted in Swiss law that 'other solutions' conceptually include the buy-out order ${ }^{43}$, there has been no decision reported by the Swiss Federal Court where such an order was delivered. ${ }^{44}$ However the TCA has adopted a clear position in favor of the buy-out remedy. Since the TCC entered into force in July 2012, seven decisions have been published where existence of just causes was confirmed. Of these seven successful cases, the TCA (i) confirmed two buy-out orders $^{45}$, (ii) reversed two decisions just because the court of first instance had not considered the buy-out remedy instead of corporate dissolution ${ }^{46}$, and finally, (iii) confirmed three dissolution orders by stating that the making of a buy-out order was impossible due to the financial situation of the company in question. ${ }^{47}$ Likewise in the $\mathrm{UK}^{48}$, it is expected that the buy-out will be the most commonly adopted remedy by Turkish judges, as it seems to be the most efficient one ${ }^{49}$, particularly for closely held joint stock companies. Therefore Turkish courts' preference in favour of buy-out order may render such remedy a right accruing to the claimant as it is considered so under English law. ${ }^{50}$

39 Habegger 1996, p. 288; Kunz 1998, p. 240.

40 Hawkes v Cuddy [2009] EWCA Civ 291.

41 Re J E Cade and Son Ltd [1992] BCLC 213, p. 223.

42 Worthington 2016, p. 726. See Grace v Biagioli [2005] EWCA Civ 1222 and Re Scitec Group Ltd [2011] 1 BCLC 277.

43 Habegger 1996, p. 182; Stoffel (von Büren/Weber) 2001, para 1324; Meier 2005, para 16.9; von der Crone 2014, p. 586. The Swiss Federal Court affirmed this approach at ATF 126 III 266, p. 272 and BGE 138 III 294, S. 303.

44 Kunz 1998, p. 242; Şahin 2013, p. 391.

45 TCA 11. Civil Division Date 11.6.2015 Case No. 2015/2255 Decision No. 2015/8166; Date 19.11.2015, Case No. 2014/17416, Decision No. 2015/12331.

46 TCA 11. Civil Division Date 2.6.2014, Case No. 2014/3669, Decision No. 2014/10238; Date 3.3.2016 Case No. 2015/9088 Decision No. 2016/2352.

47 TCA 11. Civil Decision Date 6.7.2015, Case No. 2014/17428, Decision No. 2015/8840; Date 12.10.2015, Case No. 2015/6768, Decision No. 2015/10302; Date 14.12.2015, Case No. 2015/6751, Decision No. 2015/13424.

48 In almost all successful unfair prejudice cases, the court ordered buy-out of the claimant. See Worthington 2016, p. 725; Davies/Worthington 2016, para 20-19; Mayson/French/Ryan 2016, p. 695. Of 233 petitions against unfair prejudice issued between January 1994 and December 1996 to the Companies Court at the Royal Courts of Justice, 69 \% sought an order that the petitioner's shares be bought and $23.6 \%$ sought an order that the respondents sell their shares. See The Law Commission Report "Shareholders' Remedies", Law Com No 246, Cm. 3769, October 1997, Appendix J, pp. 176-180.

For English law, see Scottish Co-operative Wholesale Society Ltd v Meyer [1959] AC 324 (House of the Lords); Prentice 1988, p. 83; Worthington 2016, p. 732. For Swiss law, see Habegger 1996, p.182; Beeler/von de Crone 2010, p. 338. For Turkish law, see Çamoğlu 2008, p. 72; Şahin 2013, p. 416.

50 It is suggested that TCC Article 531 encourages courts towards adopting the buy-out remedy, see Tekinalp 2013, p. 214. 


\section{Company Being the Purchaser of Shares}

In English law, CA 2006 section 996/2-(e) explicitly permits the court to oblige the controller to purchase the claimant's shares, rather than the company. Unlike English law, the wording of TCC Article 531 and SCO Article 736/4 does not expressly allow for such an order. Therefore the prevailing doctrine in Turkish and Swiss laws has adopted the view that the court can only force the company in question to purchase the claimant's shares, rather than the oppressive controller. ${ }^{51}$ However, it follows that the controller is not directly liable for the implicit price of her unfair conducts. This is, in our view, one of the most important defects of the provision, because it decreases the expected incentives on the controller. By contrast, the court should be able to order purchase of the claimant's shares by the controller. Hence the wrongdoer should be made liable for her conducts.

Two reasons are asserted to be underlying this problem. Firstly, it is argued that the respondent of an action for dissolution can only be the company in question, and hence, the court cannot deliver a judgment binding a person who is not a party to the proceeding. ${ }^{52}$ This argument is based on procedural law and it is followed by the TCA as well. ${ }^{53}$ Some authors suggests that the court may order the controller to purchase the claimant's shares in cases where the former joins the proceeding and agrees to do so. ${ }^{54}$ However, the intervener is not deemed a 'party' to the proceeding, and thus, the controller's intervention would not allow the court to oblige the former to purchase the claimant's shares. ${ }^{55}$ The problem can be overcome by allowing the minority to show the controller as a respondent along with the company in question. This view has been adopted by certain authors $^{56}$, and it would require a change of the TCA's position to date. An alternative solution would be to adopt a legislative amendment in parallel with CA 2006 section 996/2-(e) in this regard, which would clearly enable the claimant to show the controller respondent in her petition. Once this hurdle is cleared, the court may even entitle the claimant to purchase the shares of the oppressive controller who is shown as respondent along with the company. ${ }^{57}$ Such a remedy would be appropriate for both the rightful party and the company in question, particularly in deadlock situations, since that would result with the buy-out of the wrongful party.

51 For Turkish law see Çamoğlu 2007, pp. 683-684; Sumer 2010, p. 117; Tekinalp 2013, p. 218; Erdem 2012, p. 267; Şahin 2013, p. 421; Hanağası 2016, p. 256. For Swiss law see Lüscher 1992, p. 182; Handschin 1993, p. 45; Kunz 1998, p. 244; Böckli 2009, p. 2325; Vogt/Enderli 2010, p. 244; Druey/Just/Glanzmann 2015, p. 221. Cf. Watter 1993, p 124.

52 Şahin 2013, p. 421; Tekinalp 2013, p. 218; Hanağası 2016, p. 256; Handschin 1993, p. 45; Kunz 1998, p. 244.

53 TCA 11. Civil Division Date 26.5.2014, Case No. 2014/3356, Decision No. 2014/9659; Date 23.12.2015, Case No. 2015/5994, Decision No. 2015/13820; Date 28.1.2016, Case No. 2015/2939, Decision No. 2016/937. Although the 11. Civil Division softened its approach in one decision (Date 10.6.2015, Case No. 2015/2387, Decision No. 2015/8048), it took a step back in a subsequent one (Date 3.3.2016, Case No. 2015/12197, Decision No. 2016/2357).

Handschin 1993, p. 45; Girod 1986, p. 27-28.

55 Pekcanıtez/Atalay/Özekes 2011, p. 222; Postacıoğlu/Altay 2015, para 1421; Böckli 2009, p. 2325 fn. 505.

56 In Turkish law, Ayoğlu recommends this solution exclusively for deadlock situations experienced at \%50-\%50 shareholding structures in order to allow the buy-out of the wrongful party (Ayoğlu 2013, p. 243). While Yüksel supports this approach in privately held joint stock companies with shareholders having close relationship (Yüksel 2017, p. 881), Aker holds with this opinion without indicating an exception (Aker 2016, p. 138-139). In Swiss law, a courtordered auction for the claimant's shares where the majority shareholder has to participate is suggested by von der Crone (von der Crone 1993, p. 42-43; Beeler/von de Crone 2010, p. 339). Swiss Federal Court accepted von der Crone's suggestion in BGE 138 III 294, p. 303, E. 3.3.3.

57 In Turkish law, this solution is supported by Ayoğlu in case where there is an equality of shareholdings (Ayoğlu 2013, p. 243). Under English law such orders have occasionally been given by courts, see Re Brenfield Squash Racquets Club Ltd [1996] 2 BCLC 184; Clark v Cutland [2003] 2 BCLC 393; Oak Investment Partners XII v Boughtwood [2010] 2 BCLC 459; Re Abbington Hotel Ltd [2012] 1 BCLC 410. 
The second reason is based on the principle of sole liability of shareholder vis-à-vis the company (la responsabilité limitée interne / beschränkte Haftung des Aktionärs nach innen) which is enshrined in TCC Article 480/1 and SCO Article 680/1. The principle of sole liability is distinguished from the limited liability of shareholder vis-à-vis corporate creditors (la responsabilité limitée externe / beschränkte Haftung des Aktionärs nach außen) ${ }^{58}$ According to the principle of sole liability, no obligation other than payment of the subscribed capital can be incurred upon shareholders in joint stock companies. Therefore it is argued that forcing the controller to purchase the claimant's shares would violate this principle. ${ }^{59}$ However, it must be noted that a buyout order would not incur further obligation upon a shareholder vis-à-vis the company, but the claimant. Therefore, the principle of sole liability would not constitute an impediment to a buy-out order, if it is accepted that the principle is only applicable with respect to obligations vis-à-vis the company. ${ }^{60}$

\section{Valuation of Shares}

Two main problems regarding valuation of the claimant's shares are addressed here: i) the basis of valuation and ii) the date on which they are to be valued. TCC Article 531 reads as: "...real value of their shares that are valued on the closest date to the judgment...". As to the first question, it is understood that neither liquidation (break up) nor market value is taken as a basis. However the "real value" is an ambiguous concept that is not able to guide the court as to whether shares are valued on pro rata or discounted basis, and it does not refer to a specific valuation method. ${ }^{61}$ Similar terms, such as 'full', 'adequate' and 'reasonable' value are used in the TCC and Capital Markets Law numbered 6362.

Considering that the promisee is entitled to the benefit she would have obtained from performance of the promise $^{62}$, the payment of "real value" has to provide the leaving shareholder with the same economic condition as she would have, if she remained in the company. ${ }^{63}$ Furthermore, since the buy-out remedy is to function as an implicit price of oppression, the controller should be worse off under a court ordered valuation than one arrived at by negotiation. ${ }^{64}$ Only in this way can the threat of a purchase order strengthen the minority's negotiation power, and thus, incentivize the controller to respect the former's interests. Given these, valuation must be made, in principle, on a going concern ${ }^{65}$ and pro rata basis, despite the fact that it is ex hypotesi a minority holding and

58 Meyer 1935, p. 58; Naegeli 1948, p. 23.

59 Şahin 2013, p. 421; Sanwald 2009, 171; Vogt/Enderli 2010, p. 244. Vogt/Enderli suggest that a dissolution order can be given with the condition that the company would be dissolved, unless the claimant's shares are purchased within a given period.

60

TCC Article 202 prescribes a buy-out remedy in favour of minorities within groups of companies, whereby it is expressly provided that the claimant's shares are purchased by the controlling shareholder in the event that the subsidiary suffers loss or is subjected to an unfair material transaction, such as merger, spin-off, dissolution etc. For detailed information see Okutan Nilsson 2009, pp. 382-385, 409-412.

61 While pro rata value excludes the control prime by simply dividing the total value of the company by the proportion of the shareholding, discounted basis values each minority share less than that of the majority

62

Cooter/Ulen 2016, p. 281.

63 Şahin 2013, p. 462.

64 Prentice 1988, pp. 83-84.

65 Joffe et al. 2015, p. 409. 
so does not carry the control rights. ${ }^{66}$ However, as in English law, discount basis seems adequate where the minority holds her shares purely as a form of investment, rather than using her participation rights and there is restriction on share transfers. ${ }^{67}$

In respect of the date of valuation, the date closest to the judgment is the choice of the Turkish legislator. Yet, this may impair the minority's rights by providing less than she would have obtained if there was no oppressive conduct at all. Because abusive conducts in all likelihood are reflected in the value of the company, consequently that of shares. The valuation at the closest date to the judgment, thus, transfers certain part of the costs generated by the controller to the minority. Furthermore, the controller is incentivized to further attempt to decrease the company's value until the date of the judgment. Although the express wording of the provision does not allow for adopting an alternative date, there is no impediment to taking into account any depreciation due to the wrongs complained of, as English courts do. ${ }^{68}$

\section{Conclusion}

Shareholders representing at least ten per cent of the share capital in joint stock companies, and five per cent in publicly traded companies, are granted the right to request corporate dissolution for just causes under TCC Article 531. Aside from corporate dissolution, the court is entitled to order buy-out of the claimant's shares or to adopt a different solution. As it is already signalled by the TCA's decisions to date, the buy-out is expected to be the most commonly adopted remedy by Turkish judges.

The order for the purchase of the claimant's shares at 'real' value is expected to operate as a put option conditional upon serious oppression. Hence the remedy is supposed to ex ante incentivize the majority towards respecting the minority's interests. However, we argue that TCC Article 531, in parallel with SCO Article 736/4, is not designed so as to provide the expected incentives. In this regard, referring to the solutions that have developed in English law seems to be helpful. Hence we suggest that (i) the relief sought by the claimant should be taken into account, (ii) the purchaser of the claimant's shares should be the controller, rather than the company in question (iii) the standard of 'just cause' to be proven should not be equal for each remedy, and thus, the courts should be able to give a buy-out order even if the facts do not justify corporate dissolution, (iv) dissolution order should not be given in cases where there is a going-concern value to protect, and finally, (v) valuation of the claimant's shares should be made, in principle, on a going concern and pro rata basis, and any depreciation of the claimant's shares due to the controller's abusive conducts should be taken into account.

66 Boyle 2002, p. 106; Worthington 2016, p. 741-743.

Boyle 2002, p. 108; Birds 2013, p. 981; Joffe et al. 2015, pp. 409-410. The fact that the shareholder does not have an active involvement in the company may show that her utility of being a shareholder is less than the shareholders who actively attempt to use her administrative rights as well. See Consultative Report, p. 98.

68 Re McCarthy Surfacing Ltd [2008] EWHC 2279 Ch. Davies/Worthington 2016, para 20-20. 


\section{Bibliography}

\section{Books and Articles}

Aker H (2016) Anonim ve Limited Şirketlerde Ortaklık Sıfatının Sona Ermesi ve Özellikle Haklı Sebeple Fesih Davasına İlişkin Bazı Değerlendirmeler. BATİDER C. XXXII S. 1: 63-150

Ayoğlu T (2013) Anonim Ortaklıkların Haklı Nedenle Feshi. GSÜHFD Prof.Dr.Oğuz İmregün'e Sayg1 Sempozyumu, 2013/2: 219-252

Beeler L, Crone H C von der (2010) Auflösungsklage nach Art. 736 Abs.4 OR. Entscheid des Schweizerischen Bundesgerichts 4A_475/2009 vom 5. Marz 2010. SWZ: 329-339

Birds J (2013) Annotated Companies Legislation. OUP, Oxford

Boyle A J (2002) Minority Shareholders’ Remedies. CUP, Cambridge

Böckli P (2009) Schweizer Aktienrecht. Schultess, Zürich/Basel/Genf

Bürgi F W (1969) Kommentar zum Schweizerischen Zivilgesetzbuch, V. Band Obligationenrecht, 5. Teil: Die Aktiengesellschaft. Schultess, Zürich

Dessemontet F, Rapp J M, Stoffel W (1993) Travaux Preparatoires du Droit des Societes Anonymes, recueil compilé par Olivier Schaller et Denis Weber. CEDIDAC, Lausanne

Cooter R, Ulen U (2016) Law \& Economics. Addison-Wesley, http://scholarship.law.berkeley.edu/books/2/

Çamoğlu E (2007) Anonim Ortaklığın Haklı Sebeple Feshi. In: Alangoya Y (eds), Prof.Dr.Yavuz Alangoya İçin Armağan. Beta, İstanbul, pp 667-684

Çamoğlu E (2008) Kollektif Ortaklığın Haklı Sebeple Feshi ve Ortağın Haklı Sebeple Çıkarılması. Vedat, İstanbul

Çamoğlu E (2015) Anonim Ortaklığın Haklı Sebeple Feshinde Hakimin Takdir Yetkisi. BATİDER C. XXXI S. 1: $5-19$

Davies P, Worthington S (2016) Gower and Davies’ Principles of Modern Company Law. Sweet \& Maxwell, London

Druey J N, Just E D, Glanzmann L (2015) Gesellschafts- und Handelsrecht. Schultess, Zürich

Erdem N (2012) Anonim Ortaklı̆̆ın Haklı Sebeple Feshi. Vedat, İstanbul

Gilson R, Kraakman R (1984) The Mechanisms of Market Efficiency. Virginia Law Review V. 70 May: 549643

Girod C G (1986) The Close Corporation and the Buyout Right of Minority Shareholders in the United Stated and in Switzerland. Thesis, Harvard Law School

Gordon J N (1989) The Mandatory Structure of Corporate Law. Colum. L. Rev V. 89/7: 1549-1598

Habegger P (1996) Die Auflösung der Aktiengesellschaft aus wichtigen Gründen. Stämpfli Verlag, Zürich

Hanağası E (2016) Anonim Ortaklığın Haklı Sebeple Feshi Davasının Medenî Usûl Hukuku Perspektifinden Değerlendirilmesi. BATIDER C. XXXII S. 1: 199-270

Handschin L (1993) Auflösung der Aktiengesellschaft aus wichtigem Grund und andere sachgemässe Lösungen. SZW (RSDA) 1/93: 43-45 
Honsell H, Vogt N P, Watter R (2016) Basler Kommentar, Obligationenrecht II. Art. 620-964 OR. Schultess, Basel-Genf-München

Joffe V, Drake D, Richardson G, Lightman D, Collingwood T (2015) Minority Shareholders: Law, Practice and Procedure. OUP, Oxford

Kraakman R, Armour J, Davies P, Enriques L, Hansmann H, Hertig G, Hopt K, Kanda H, Rock E, (2009) The Anatomy of Corporate Law: a Comparative and Functional Approach. OUP, Oxford

Kunz P V (1998) Zur Auflösungsklage gemass Art. 736 Ziff. 4 OR - Garant für ein indirektes Austrittsrecht?. In: von Büren R, Aktienrecht 1992-1997: Versuch einer Bilanz Zum 70. Geburtstag von Rolf Bär. Stämpfli Verlag, Berne, pp 235-248

Lüscher C (1992) Die Auflösung von Handelsgesellschaften aus wichtigen Gründen. Diss. Basel

Manne H G (1965) Mergers and the Market for Corporate Control. The Journal of Political Economy 73/2: 110120

Mayson D, French D, Ryan C (2016) Mayson, French \& Ryan on Company Law. OUP, Oxford

Meier R (2005) Die Aktiengesellschaft. Schultess, Zürich-Basel-Genf

Meyer O (1935) Des Versements Supplémentaires Des Actionnaires. Thèse, Lausanne

Naegeli W (1948) Der Grundsatz der beschränkten Beitragspflicht, insbesondere der Ausschluss der Nachschlusspflict im Aktienrecht. Ernst Lang, Zürich

Nomer Ertan F (2015) Anonim Ortaklığın Haklı Sebeple Feshi Davası - TTK m. 531 Üzerinde Düşünceler -. İ̈HFM C. LXXIII S. 1: 421-440

Okutan Nilsson (2009) Türk Ticaret Kanunu Tasarısı'na Göre Şirketler Topluluğu Hukuku. On İk Levha, İstanbul

Oruç M (2011) Yeni TTK’ya Göre Anonim Ortaklıktan Çıkarılma, BATİDER C. XXVII S. 1: 209-233

Pekcanitez H, Atalay O, Özekes M (2011) Medeni Usul Hukuku. On İk Levha, Ankara

Prentice D (1988) The Theory of the Firm: Minority Shareholder Oppression: Sections 459-461 of the Companies Act 1985. Oxford Journal of Legal Studies V. 8 No. 1: 55-91

Postacığlu İ E, Altay S (2015) Medeni Usul Hukuku Dersleri. Vedat, İstanbul

Riley C A (1992) Contracting Out of Company Law: Section 459 of the Companies Act 1985 and the Role of the Courts. The Modern Law Review V. 55 No. 6 November: 782-802

Sanlı K C (2007) Haksız Fiil Hukukunun Ekonomik Analizi Hukuk ve Ekonomi Öğretisi. Beta, İstanbul

Sanwald R (2009) Austritt und Ausschluss aud AG und GmbH. Dike, Zürich/St.Gallen

Sumer A (2010) Türk Ticaret Kanunu Tasarısında Anonim Ortaklıkların Haklı Sebeple Feshi. MÜİİF Dergisi C. XXVIII S. 1: 171-181

Şahin A (2013) Anonim Ortaklı̆̆ın Haklı Sebeple Feshi. Vedat, İstanbul

Tekinalp Ü (1974) Türk Ticaret Kanunundaki Boşluk: Anonim Ortaklığın Önemli Sebeplerle Feshi, Çoğunluk Gücünün Kötüye Kullanılmasına Karşı Etkili Bir Araç. İktisat ve Maliye Dergisi C.XXI S.8: 321-326

Tekinalp Ü (2013) Haklı Sebeplerle Fesih Davasının Bazı Usuli Sorunları. In: Ulusoy E, Çamoğlu E (eds), Ersin Çamoğlu'na Armağan, Vedat, İstanbul, pp 211-222

Vogt H, Enderli T (2010) Die Auflösung einer Aktiengesellschaft aus wichtigen Gründen und die Anordnung 
einer "anderen sachgemässen Lösung" (Art. 736 Ziff. 4 OR). recht. Zeitschrift für juristische Weiterbildung und Praxis $28,238-250$

von Büren R, Stoffel W A, Weber R H (2011) Grundriss des Aktienrechts. Schultess, Zürich

von der Crone H C (1993), Lösung von Pattsituationen bei Zweimanngesellschaften. SJZ 89: 37-44.

von der Crone H C (2014) Aktienrecht. Stämpfli Verlag, Bern

Worthington S (2016) Sealy and Worthington's Text, Cases and Materials in Company Law. OUP, Oxford

Yasaman H (2009) Türk Ticaret Kanunu Tasarısı'nda Hakimin Genişleyen Rolü. BATIDER C. XXV S. 4: 73-94

Yüksel S (2017) Anonim Ortaklığın Haklı Sebeple Feshi Davasında Davalı Sıfatı Üzerine Düşünceler. Prof. Dr. Hamdi Yasaman'a Armağan, İstanbul, 663-881

\section{Documents}

Law Commisson, Shareholder Remedies (Consultation Paper No 142), 1996 http://awcommission.justice.gov.uk/docs/cp142 Shareholder Remedies Consultation.pdf. (Consultative Report)

Law Commisson, Shareholder Remedies (Law Com Report No 246), 1997 http://lawcommission.justice.gov.uk/docs/lc246 Shareholder Remedies.pdf. (Law Com Report)

Report of the Company Law Committee, Cmnd. 1749, June 1962, http://www.takeovers.gov.au/content/Resources/other resources/downloads/jenkins committee v2.pdf.

Company Law Review, Modern Company Law for a Competitive Economy: Developing the Framework, URN 00/656, March 2000 , http://webarchive.nationalarchives.gov.uk/20121029131934/http:/www.berr.gov.uk/whatwedo/businesslaw/coact-2006/clr-review/page25086.html.

The Law Commission Report “Shareholders’ Remedies”, Law Com No 246, Cm. 3769, October 1997.

Report of the Committee on Company Law Amendment (1945) Cmd 6659, http://www.takeovers.gov.au/content/Resources/other resources/Cohen Committee.aspx. 